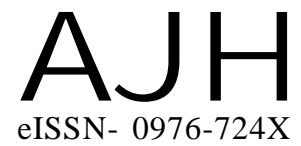

Received : 21.09.2016

Revised : 18.11 .2016

Accepted : 28.11.2016

Members of the Research Forum

Associated Authors:

${ }^{1}$ Department of Agricultural

Economics, Dr. B.S. Konkan Krishi

Vidyapeeth, Dapoli, RATNAGIRI

(M.S.) INDIA
Author for correspondence : P.J. KSHIRSAGAR

Department of Agricultural Economics, Dr. B.S. Konkan Krishi Vidyapeeth, Dapoli, RATNAGIRI (M.S.) INDIA

Email : hodecon@rediffmail.com
THEASIAN JOURNAL OF HORTICULTURE

Volume 11 | Issue 2 | December, 2016 | 401-407

Visit us -www.researchjournal.co.in

RESEARCH PAPER
DOI : 10.15740/HAS/TAJH/11.2/401-407

\title{
Resource use efficiency of bitter gourd in Konkan region (M.S.)
}

\section{P.J. KSHIRSAGAR, J.M. TALATHI ${ }^{1}$ AND S.S. WADKAR ${ }^{1}$}

ABSTRACT : Resource use efficiency of production of bitter gourd (Momordica charantia L.) in Konkan region (M.S.) was undertaken with a cross sectional sample of 120 bitter gourd cultivators. The per hectare physical input utilization indicated that, the proportion of family labour days was more $(53.50 \%)$ than hired labour days $(46.00 \%)$ with per hectare average of 267.84 labour days. Regarding other inputs Rs.5045.00 of supporting and shading materials, $148.90 \mathrm{~kg} \mathrm{~N}, 116.60 \mathrm{~kg} \mathrm{P}_{2} \mathrm{O}_{5}, 19.88 \mathrm{~kg} \mathrm{~K} \mathrm{O}, 34.58 \mathrm{q}$ FYM, $637.07 \mathrm{~kg}$ mulching materials, and netting materials Rs.1242.40 wire and Rs.1200.00 net and $13.40 \mathrm{hrs} / \mathrm{ha}$ of machine labour were used. The Cobb-Doug production function analysis revealed that, the intensive use of seed $(\mathrm{kg})$, fertilizers $(\mathrm{kg})$, irrigation ( $\mathrm{hrs}$ ) and supporting materials had positive and significant influence on production. The co-efficient of determination $\left(\mathrm{R}^{2}\right)$ indicated that 86.00 per cent variation in bitter gourd production. The functional analysis indicated to reallocate available resources to increase the profit from cultivation of bitter gourd by proper management of available resources and given technology.

KEY WORDS : Bitter guard, Resource use efficiency, Marginal value product, Factor cost

HOW TO CITE THIS ARTICLE : Kshirsagar, P.J., Talathi, J.M. and Wadkar, S.S. (2016). Resource use efficiency of bitter gourd in Konkan region (M.S.). Asian J. Hort., 11(2) : 401-407, DOI : 10.15740/ HAS/TAJH/11.2/401-407. 